\title{
Justin Trudeau on Increasing the Role of Canada in the
}

\section{International Stage}

\section{Andrea Celine Nugroho}

Mahasiswa Jurusan Hubungan Internasional, Fakultas IImu Sosial dan IImu Politik, Universitas Katolik Parahyangan

\begin{abstract}
Abstrak
Kanada telah menjalani 9 tahun di bawah pemerintahan Partai Konservatif dan Stephen Harper sebagai Perdana Menteri hingga Oktober 2015. Kebijakan luar negeri yang dianut juga didasarkan pada pandangan kaum konservatif sebagai partai utama di Kanada. Terpilihnya Justin Trudeau dari Partai Liberal menjadi Perdana Menteri Kanada ke-23, menggantikan Stephen Harper, membawa Kanada pada arah baru kebijakan luar negeri dan peran Kanada di kancah internasional. Trudeau telah memperlihatkan dirinya sebagai pemimpin dunia muda yang membawa inovasi dan perubahan yang sesuai dengan perkembangan zaman. Terobosan baru dalam politik luar negeri yang berbeda dengan Perdana Menteri Kanada sebelumnya dan keaktifannya melakukan diplomasi publik menyebabkan Trudeau menjadi figur politisi baru yang fenomenal. Lewat pemerintahan Trudeau, Kanada akan semakin memperluas pengaruh dan perannya dalam kancah internasional. Cara Trudeau dalam menyelesaikan agenda politik luar negerinya serta membangun citra baru Kanada yang lebih aktif di dunia internasional patut diulas lebih lanjut dengan menggunakan konsep public diplomacy dan pendekatan bureaucratic structures and processes to foreign policy, yang berfokus pada organizational processes model.

Kata kunci: Justin Trudeau, Liberal Party, Canada's foreign policy, public diplomacy, Canada.
\end{abstract}

\section{INTRODUCTION}

Since the Liberal Party won the federal election of Canada last year in 2015, the world directed more attention to Canada. Headline news, on the internet, spoke frequently about the new and young Prime Minister of Canada from the Liberal Party, Justin Trudeau. His lively presence and handsome face are not the only thing that managed to steal the spotlight, his direction of policies have also made Canadian, and even the international society, put big expectations on him. People are counting on Trudeau to bring change, not only to Canada but also the world.

From the start of his campaign, Trudeau and the Liberal had made some commitments, particularly about bringing a more inclusive Canada and rely on

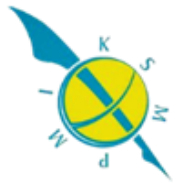


building a strong middle class. ${ }^{1}$ Trudeau and the Liberal's focus on contemporary issues in Canada and the world have brought them more support. Before the Liberal Party came to power and Justin Trudeau assigned as the Prime Minister, Canada was ruled by the Conservative Party and led by Stephen Harper as the $22^{\text {nd }}$ Prime Minister for over nine years and three terms in power since 2006. In terms of foreign policy, Stephen Harper led the Conservative way of Canadian even more into economic stability and military power over cooperation in international organizations and diplomacy. ${ }^{2}$ Canada, in the power of Conservative, had been attached to the role of a state that only focused on traditional issues in foreign affairs.

The face of Canadian foreign policy in the Conservative era focused on supporting the economic growth of its people also protecting Canada's sovereignty and interest in the world stage through its military forces. Conservative government led Canada to economic recovery after the global recession, created 1.2 million net new jobs, and lowered taxes. ${ }^{3}$ Also, Canada was more concerned to the military and anti-terrorism measures, notably in the Middle East from the deployment of troops to Afghanistan in 2001, defended Israel in the Israel-Lebanon conflict in 2006 and a fight against the Islamic State in Iraq and Syria (ISIS). It can be confirmed that the foreign policy during Stephen Harper era as Prime Minister emphasized more on the hard power of Canada in international stage.

Besides focusing on economic growth and the use of military forces in international stage, the foreign policy of Conservative Party also highlighted the failure of Canada to obtain the UN Security Council seat in 2010. It was a big embarrassment that Canada had to bear. Other main issue would be Canada's withdrawal from Kyoto Protocol regarding the climate change issue on reducing

1 "Real Change," Liberal Party of Canada, accessed on November 19, 2016, https://www.liberal.ca/realchange/

2 “Our History," Conservative Party of Canada, accessed on November 20, 2016, http://www.conservative.ca/our-party/our-history/

${ }^{3}$ Ibid 
emission. ${ }^{4}$ These facts proved that Canada was still on the conservative mindset, and therefore, limited its role on the current affairs in international stage.

In this fast-changing world, it is important to engage more with the society and adapt to the current international affairs than focusing only on the traditional issues of international affairs. The involvement from all states is needed to solve the current international affairs, such as climate change, gender equality, migration, economic development, etc. There is no exception for Canada. Canada needs to change its old way, as Canada have to give more contribution more on solving the current issues together with other countries. Therefore, this paper is going to focus on how Justin Trudeau, the new Prime Minister, increased the role of Canada in the international stage for one year of his reign.

\section{Organizational Processes Model Approach and the Concept of Public Diplomacy}

The writer of this paper will use two frameworks to explain and elaborate how Justin Trudeau increased Canada's role in the international stage. The first is organizational processes model approach in the making of foreign policy, which considered best to observe the change in Canadian foreign policy from the Conservative era to Liberal era. The second is public diplomacy that will be used to examine Justin Trudeau's approach and engagement to the people of Canada and the international society to increase the role of Canada.

Graham Allison on Essence of Decision analyzed the 1962 Cuban missile crisis using the approach of bureaucratic structures and processes in the making of foreign policy. ${ }^{5}$ There are three ways of understanding the decision made by US

\footnotetext{
${ }^{4}$ Mohamed Hashem, "Canada's election and foreign policy foibles," Al-Jazeera, October 16, 2015, accessed on November 20, http://www.aljazeera.com/indepth/features/2015/10/canada-election-foreign-policy-foibles151016100443697.html

${ }^{5}$ Robert Jackson and Georg Sorensen, Introduction to International Relations; Theories and Approaches Fifth Edition, (Oxford: Oxford University Press, 2013); 255.
}

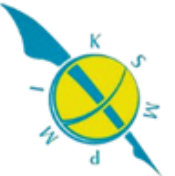


during the crisis: rational actor approach, organizational processes model and bureaucratic politics model. In this paper, the focus would be on the 'organizational processes model' in understanding the foreign policymaking of Canada in the reign of Justin Trudeau.

The organizational processes model focused on emerging from clusters of governmental organizations that look after their own best interests and follow 'standard operating procedures'. ${ }^{6}$ This means that the existing government or legislative will follow the 'standard operating procedures' regarding the decision making of foreign policy, but also did not forgetting their own interest. In Canada, the direction of foreign policy is determined by the political party who won the federal election and appointed its political party leader as the Prime Minister. The political party who won the federal election will established policies, notably foreign policy, based on their own interest but still following the 'standard operating procedures' or the main legislation existed in Canadian government.

The concept of public diplomacy is chosen as the best concept to give more comprehensive explanation on how Justin Trudeau, as the Prime Minister, increasing the role and bringing the world's attention to Canada. Public diplomacy is one of soft power's instruments in managing and communicating with multiple actors from the official government, international organization, business and citizens. Public diplomacy's aim is to promote, inform, and influence the people both in the country and overseas. Also, this will build a relationship for the purposes of national interest and advancing foreign policy. ${ }^{7}$

Based on this concept, Justin Trudeau used public diplomacy in order to be engaged with people in Canada and overseas. One of his strategies was the use of social media in order to promote the progress of his government and foreign policy through Instagram and Twitter. The social media is borderless so that many people

\footnotetext{
${ }^{6}$ Ibid.

7 "Defining Public Diplomacy," University of Southern California Center on Public Diplomacy, accessed on November 20, 2016, http://uscpublicdiplomacy.org/page/what-pd
} 
will know his policies and activities. He also openly stated his official statements and opinions regarding the direction which Canada will take in terms of foreign policy. Trudeau was promoting on how Canada is a strong and inclusive country, all for the sake of increasing Canada's role in international stage.

\section{The New Face of Canada's Foreign Policy}

Conservative Party in Canada had ruled since 2006 until 2015 with Stephen Harper appointed as the $22^{\text {nd }}$ Prime Minister. In October 2015, Liberal Party won the federal election with 184 seats out of 338 seats in the House of Commons and Justin Trudeau became the next Prime Minister of Canada. ${ }^{8}$ With the Liberal Party came to power in Canada, the direction of foreign policy has shifted to accommodate the interests of Liberal but still in line with the Canadian existing legislation. Thus, Canada's foreign policy will have a different direction from the one the Conservative Party initiated.

As explained before, Stephen Harper led the Conservative way of Canadian foreign policy through the economic growth and military forces, but he did not focus on the diplomacy and Canada's role in the international organization. Harper focused on the hard power of Canada in its foreign policy through the deployment of the military forces to the Middle East countries in order to support the war on terror established by the United States. Canada also supported the Ukraine government when the conflict occurred between Russian and Ukraine. It was also confirmed that Canada had no intention on participating in the climate change issue by abandoning the Kyoto Protocol's second commitment in $2011 .{ }^{9}$

\footnotetext{
${ }^{8}$ The Data Team, "Canada's 2015 federal election result," The Economist, October 20, 2015, $\begin{array}{llll}\text { accessed } & \text { on } & \text { November } & 23,\end{array}$ http://www.economist.com/blogs/graphicdetail/2015/10/daily-chart-9

9 "Canada pulls out of the Kyoto Protocol," The Guardian, December 13, 2011, accessed on November 22, 2016, https://www.theguardian.com/environment/2011/dec/13/canada-pullsout-kyoto-protocol
} 
In the reign of Justin Trudeau and the Liberal Party, the foreign policy of Canada shifted from the hard power to soft power. Canada, through the Liberal Party, has given label to its foreign policy by the name of 'responsible conviction' which still incorporates the Conservative way of foreign policy as well as bring a new focus on multilateralism, the United Nations, fighting climate change, and different approaches toward current international issues, such as ISIS, and other conflicts.

The shift in Canadian foreign policy signaled the change and new approaches which can increase the role of Canada in international stage. In 2011 Canada had abandoned a commitment for fighting the climate change, now Canada has committed to become the global leader in resolving the issue of climate change ${ }^{10}$ Canada stated its plan publicly on obtaining the UN Security Council seat in 2020 as a nonpermanent member for a two year term, despite the major loss for losing the UNSC seat in 2010 .

In the Conservative era, the refugee claims processing were getting delayed and there was prevention on the arrival of the refugees from Syria. While in the Liberal era, Canada had promise to take 25.000 refugees and Trudeau also seen welcomed the small group of refugees personally. ${ }^{11}$ This was a shift in the Canadian foreign policy as Trudeau also gathered support for the refugees at the United Nations conference.

Besides shifting the direction of foreign policy, Trudeau also focused on building network and relationship with other countries through bilateral and multilateral meetings. Canada has strengthened its ties even more to the United States and Mexico as a neighbor in North America. Canada had also promoted relationship

\footnotetext{
10 "Canada's Priorities for COP 22," Government of Canada, accessed on November 24, 2016, http://www.climatechange.gc.ca/default.asp?lang=En\&n=EF6CE373-1

11 Antonia Zerbisias, "Note to leaders: this is how to welcome refugees," Al-Jazeera, December 14, 2015, accessed on November 24, 2016, http://www.aljazeera.com/indepth/opinion/2015/12/note-world-leaders-refugees-trudeaucanada-syria-151214051232043.html
}

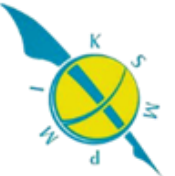


with Asian countries, notably the Southeast Asian countries through ASEAN. ${ }^{12}$ Canada has shifted its foreign policy to be more inclusive, open to cooperation and promote human rights.

\section{Justin Trudeau's Public Approach on International Society}

To increase the role of Canada in international stage, Trudeau need to use his ability on promoting and informing people through the platform of social media. Social media is now the main platform to spread fast and enormous information, not only limited to people in Canada, but also people from other countries. Trudeau used this platform to inform, promote, engage, and communicate with the international society.

This public diplomacy of Justin Trudeau has ushered him to become an international phenomenon. People around the world already saw the Prime Minister of Canada marched in the pride parade alongside the LGBT+, claimed he was a feminist, welcomed the Syrian refugees personally, forming the most multicultural cabinet, committed on fighting against the climate change and supporting the role of youth in Canada. ${ }^{13}$ Those mentioned are related to the contemporary issues in international affairs, and these days, people are more engaged with issues which personally related to them in any ways. Justin Trudeau, through its public diplomacy in social media, has successfully won the hearts of many people in Canada and the world. Trudeau's public approach has affecting people's opinion on how Canada acts and increases its role in the international stage.

\footnotetext{
12 "Canada promotes regional security and safety in Southeast Asia," Government of Canada, accessed on November 23, 2016, http://news.gc.ca/web/articleen.do? mthd=index \&crtr.page $=1 \&$ nid= $=1104109$

${ }^{13}$ Navid Hasibi, "Trudeau is Ushering Canada Into the New Age of Foreign Policy," The Huffington Post Canada, April 4, 2016, accessed on November 20, 2016, http://www.huffingtonpost.ca/navid-hassibi/trudeau-foreign-policy_b_9602962.html
} 


\section{CONCLUSION}

The Conservative era had ended and it was the time for the Liberal Party to shift the direction of Canada to be more open and inclusive toward current international affairs. Prime Minister Justin Trudeau came to power with hope and change for Canada and the world. In the one year of his reign, he has proven to increase the role of Canada in international stage by using the shift focus in foreign policy matters and the use of public diplomacy, with more engagement and aiming for significant role in the international organization, strengthening cooperation with allies and other countries outside the allies, and being more involved in bringing solution to the current world affairs

\section{BIBLIOGRAPHY}

"Canada Promotes Regional Security And Safety In Southeast Asia - Canada News Centre". 2016. News.Gc.Ca. http://news.gc.ca/web/articleen.do?mthd=index\&crtr.page $=1 \&$ nid $=1104109$.

"Canada's Priorities For COP 22". 2016. Climatechange.Gc.Ca. http://www.climatechange.gc.ca/default.asp?lang=En\&n=EF6CE373-1.

"Defining Public Diplomacy". 2014. USC on Public Diplomacy. http://uscpublicdiplomacy.org/page/what-pd.

Hashem, Mohamed. 2016. "Canada's Election And Foreign Policy Foibles". Al-Jazeera. http://www.aljazeera.com/indepth/features/2015/10/canada-election-foreign-policyfoibles-151016100443697.html.

Hasibi, Navid. 2016. "Trudeau Is Ushering Canada Into The New Age Of Foreign Policy". The Huffington Post Canada. http://www.huffingtonpost.ca/navid-hassibi/trudeau-foreignpolicy b 9602962. html.

Jackson, Robert $\mathrm{H}$ and Georg Sørensen. 2013. Introduction To International Relations; Theories And Approaches. 5th ed. Oxford: Oxford University Press.

"Our History". 2016. Conservative.Ca. http://www.conservative.ca/our-party/our-history/. "Real Change". 2015. Liberal.Ca. https://www.liberal.ca/realchange/.

The Economist, 2016. "Canada'S 2015 Federal Election Result". http://www.economist.com/blogs/graphicdetail/2015/10/daily-chart-9.

The Guardian,. 2016. "Canada Pulls Out Of The Kyoto Protocol". https://www.theguardian.com/environment/2011/dec/13/canada-pulls-out-kyotoprotocol.

Zerbisias, Antonia. 2016. "Note To Leaders: This Is How To Welcome Refugees". Al-Jazeera. http://www.aljazeera.com/indepth/opinion/2015/12/note-world-leaders-refugeestrudeau-canada-syria-151214051232043.html.

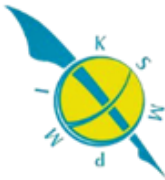

